\title{
Population growth and human resource utilization nexus in Nigeria
}

\author{
Oluyemi Theophilus Adeosun and Oluwaseyi Omowunmi Popogbe \\ Department of Economics, University of Lagos, Lagos, Nigeria
}

\begin{abstract}
Purpose - Population growth has remained a key issue facing developing economies in the world. While developed countries are experiencing diminished or negative population growth, many countries in subSaharan Africa including Nigeria are having population growth above the economic growth rate. With the deadline for the sustainable development goals approaching, attention is increasingly being focused on population growth and human capital development. Extant literature focused on population growth, human resource utilization and economic growth but this study aims to examine the effect of population growth on human resource utilization.

Design/methodology/approach - Using secondary data for the period 1990-2018, the study conducted unit root test and co-integration analyses to determine the stationarity and correlation in the long-run in the variables. The study used the error correction model to ascertain the speed at which shocks can be corrected in the long-run. Granger causality test was also carried out to ascertain the direction of causality among the variables.
\end{abstract}

Findings - The empirical results revealed that population growth has a negative and significant effect on human resource utilization. The study also revealed that unidirectional causality runs from employment rate to population growth rate and a unidirectional causality runs from employment growth rate to expected years of schooling. The Nigerian Government needs to not only control population growth but also focus on the quality of education.

Originality/value - The paper provides insights into the relationship between population growth and human capital utilization in Nigeria focusing on the 1986-2018 period.

Keywords Employment, Human resources, Utilization, VECM, Population growth

Paper type Research paper

\section{Introduction}

Population growth has remained a key issue facing developing economies in the world. While developed countries are experiencing diminished or negative population growth, many countries in sub-Saharan Africa including Nigeria are having population growth above the economic growth rate (Zahonogo, 2016; Saghir and Santoro, 2018). With the deadline for the sustainable development goals (SDGs) fast approaching, attention is

(C) Oluyemi Theophilus Adeosun and Oluwaseyi Popogbe. Published in Journal of Humanities and Applied Social Sciences. Published by Emerald Publishing Limited. This article is published under the Creative Commons Attribution (CC BY 4.0) licence. Anyone may reproduce, distribute, translate and create derivative works of this article (for both commercial and non-commercial purposes), subject to full attribution to the original publication and authors. The full terms of this licence maybe seen at http://creativecommons.org/licences/by/4.0/legalcode

The authors acknowledge everyone who has and will still contribute to the great success of this research work. Special thanks to Owolabi Kayode for his contribution towards the research.

Funding details: The authors received no direct funding for this research work.

Declaration of interest statement: The authors declare no conflict of interest.

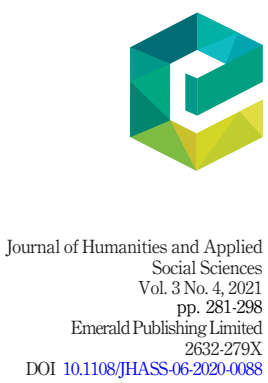


JHASS 3,4

282

increasingly being focused on population growth and human capital development (United Nations, 2015; Swain, 2018). The population growth has its benefits which include:

(1) large consumer market for both domestic and foreign products which can lead to an inflow of foreign direct investments (Bell et al., 2015; Erdogan and Unver, 2015; Nauman et al., 2016).

(2) Increase in labour force which will increase output and economic growth (Jha and Saritha, 2019; Yakubu et al., 2020). The negative effect of population growth can include:

- pressure on employment opportunities;

- pressure on infrastructure, overcrowding and standard of living; and

- Balance of payment problems as they may depend on imports or need to divert products for the export market for local consumption (Pandya and Sisombat, 2017; Gatawa et al., 2018).

Some countries especially developed nations have challenges with diminishing population growth. They have had to set up a scheme to encourage a certain type of professionals and individuals with certain skill sets to migrate into their country to improve their population growth rate (Turner, 2018; Anson et al., 2019). They are also putting in place incentives to encourage procreation and childbirth. A country such as Spain, for example, has a minister of Sex. Although they are largely capital intensive and technology savvy, they still need a reasonable population for balance (Ahmed, 2017; Chae et al., 2018). Population growth has been of interest to scholars as early as the 19th century. Malthus theory had raised concern about possible famine and the world not being able to support itself based on population growth (Deliu and Ilea, 2018; Hendrixson et al., 2020). Fortunately, industrial advancement in agriculture and other areas did not allow the fears to materialize.

The argument by scholars on the impact of population growth on development is inconclusive as outcomes from various scholars are at opposing ends. Adewole (2012) found a positive relationship between population and growth in Nigeria on one hand while Onwuka (2006) found a negative relationship between population and growth in Nigeria. In another vein, the dilution effect of population growth was considered in the study by Bucci et al. (2019) and different outcomes were found for both developing and developed countries. Even at that, development is a broad and multidimensional construct and the human capital utilization aspect needs to be further explored. Human resource is a key determinant of firm performance and an economy at large (Adewole, 2012; Ali et al., 2018; Cunningham, 2010; Okoye and Ezejiofor, 2013). It identifies the efficiency of growth and development in the country, in varying sectors; and also reveals advancement in social norms. Nigeria, like most developing nations in the world, has put in place many economic policies in her numerous attempts to use her human resources and provide employment opportunities to enhance economic growth (Isiaka and Oghenekevwe, 2019; Uneke, et al., 2017). It has a very positive effect on economic growth and economic development.

It is crystal clear that Nigeria is not just blessed with abundant deposit or supply of diverse natural resources but also highly favoured in terms of growing human population size. According to the Nigerian National Population Census conducted in 2006, the population of Nigeria, was about 140,003,542 (National Bureau of Statistics, 2009). Annually, the rate of growth stood at $3.02 \%$, with the population capable of yearly doubling itself in less than a decade time. Again, the United Nations calculation of 2016 put the Nigerian total population at $185,989,600$. As such, the country is currently the most populous in Africa (World Bank, 2016). For a country with such a huge population size, it is imperative to 
incorporate or consider human resources in any feasible economic development plan because the achievement of developmental goals and realization of its objectives highly depends on the effective utilization of qualified and committed human resources as drivers of other resources.

In spite of the rising population, numerous problems exist which hinder the productivity of human resources in the country. Ineffective human resources utilization in Nigeria results from the inability to organize, sensitize and equip the human resources for the achievement of developmental goals (Adeyemi, 2009; Fapohunda, 2012; Okoye and Ezejiofor, 2013). Although a huge amount of resources has since independence been invested by numerous bodies, government departments and institutions for the purpose of training and enhancing human resources (which by extension, was to lead to poverty alleviation); however, investment has not been commensurate with the development of human resources in Nigeria (Aliyu et al., 2014; Jaiyeoba, 2015). The increasing unemployment situation has been worrisome $(5.31 \%$ in $2015,6.03 \%$ in 2018$)$ while industrial output has been on the decline (Adeomola and Badiru, 2016; Adelowokan et al., 2019). The quality of university graduates has been called to questioning as employers say they are not workplace ready (Longe, 2017; Aloysius et al., 2018) even as their numbers continue to increase every year. The infrastructure deficiency such as epileptic electricity, bad roads and heavy traffic has furthermore contributed to the productivity and human capital output challenges (Ajide and Ridwan, 2018; Afolayan et al., 2019)

Rural-urban migration has also tilted the population growth in favour of urban centres with villages left to an ageing population and short of able-bodied people to farm. This has led to congested city centres and the development of urban slums. The detrimental trend of migration is an addition to the identified problems of human capital utilization in the country. Nyoni and Bonga (2018) asserted that migration may drain away valuable talents, as educated and motivated people are in most cases likely to migrate in search of opportunities. They asserted further that in 2014 , about $10.7 \%$ of the highly proficient population, trained in the country will be abroad working mostly in Organizations for Economic Cooperation and Development (OECD) nations. Dao (2012) also noted that $64 \%$ of Nigerian emigrants (on the average) have attained a tertiary level of education. Summarily, these are powerful indications showing that people who should be involved in enhancing the country have abandoned the nation and used their skills and intellect to aid the development of other countries.

While numerous moves have been made by the successive Nigerian Government at various times to tackle these problems, only negligible success has been attained (Adepoju, 2007; Emeh, 2012) and yet, Nigeria continues to experience population growth. Many studies have examined the relationship between population growth and economic growth; and the relationship between human resources and economic growth in Nigeria (Adenola and Saibu, 2017; Tartiyus, Dauda and Peter, 2015; Essien, 2016; Ogunleye-Adetona, 2010; Sankay, Ismail and Shaari, 2010). However, looking at the linkage human resources have with the population of a country, it is paramount at this juncture to examine the impact of population growth on the utilization of human resources in Nigeria and also to investigate the direction of their causality in Nigeria. Our a priori expectation is that an increase in population growth will increase human capital utilization in Nigeria.

The remainder of this paper proceeds as follows: Section 2 presents the theoretical and empirical review. Section 3 discusses the methodology used while the result discussions are presented in Section 4. Section 5 provides a conclusion and recommendations from the study. 


\section{JHASS 3,4}

\section{Literature review}

\subsection{Theoretical literature}

A key theory which this study hinges upon is the optimistic theory. The optimistic theory was pioneered by Ester Boserup an economist of Danish descent in 1965. She used an argument on an increase in both population and employment to challenge Malthus theory. Instead of agricultural method determining population as assumed by Malthusians, Boserup argued that population determines the agricultural method. A major theme of her work is that "necessity begets invention". Factors that distinguished Bosernp (1965) "optimistic" theory compared to that of Malthusian's "pessimistic" theory were: causal relationship from population to agricultural productivity and not vice versa; and population growth having the capacity to further trigger the use of more intensive production techniques. Therefore, in the long-run, population growth leads to a productive initiative, which, in turn, increases economic productivity.

In essence, the optimistic theory concludes that the use of the initiative to create during difficult situations is higher. An example was during the primitive time of hunters and gatherers, which was submerged by an increase in population and led to the emergence of cultivation and agriculture. When that, too, became inadequate, intensive multi-annual cropping was developed. More recently the world experienced what is known as a green revolution which has almost quadrupled world food production since 1950 using just 1\% more land and a direct reaction to population pressure (Mahmud, 2015).

In the same vein, Simon Kuznets followed the optimistic view by opining that "an increase in population means, other things being equal, increase in the labour force" (Kuznets et al., 1960). This implies that if the labour force increases at an equal pace with the total population, it will be able to turn out as much or more product per worker. Moreover, when a greater labour force is in place, untouched natural resources will be greater used. This utilization, coupled with a more specialized division of labour will lead to a greater product per worker. In the long-run, an increase in national output will occur. Simon viewed that the population is needed to handle resource scarcity and environmental problems with innovation from both the people and the markets (Mahmud, 2015). Kuznets et al. (1960) also acknowledged that increases the population can lead to the stock of the knowledge base of an economy. This is because population increase further increases the proportion of innovators in an economy and in the long-run, the growth of product per capita.

Kuznets et al. (1960), however, opined some structural changes in the economy may imply that the labour force is not directly influenced by the increase in population. Some of these structural changes that lead to "stickiness" in the reaction of the labour force are the mobility of labour and transition to industrialization. Insufficient flows of labour to improving economic opportunities may, therefore, lead to the high cost of labour and output which will further limit economic output from getting to its full capacity.

\subsection{Empirical literature}

Many empirical studies have been carried out to examine the relationship between population growth and human capital utilization with varying findings obtained. With a focus on the Ugandan economy, Klasen and Lawson (2007) examined the impact of population growth on the unemployment rate and poverty. The research was conducted using both cross-section data and panel data. The result of the estimates shows that population increase positively impacted the overall unemployment rate. However, the value is usually less than one, meaning people added are of minimal proportionate impact on unemployment. 
In a different economy, Afzal and Awais (2014) examined the relationship between population growth and employment rate in Pakistan. Using a simple model expressing the relationship between population growth and employment rate, the result found out that the numeric value signifying population is negative and not zero which tells that increase in population, unfavourably affects employment rate. This does not support the view that the rise in population is not a real problem. High population growth has become an important limiting factor for achieving the overall development goals. Afzal and Awais (2014) findings can be seen to imply the same as those of Klasen and Lawson (2007).

To analyse the relationship between population growth and per capita growth, Emeh, (2012) has developed a model in which technical advancement, human capital and population interrelate endogenously. We find a mixed result in this study. Population growth could have both positive and negative bearings on the advancement of the economy and the outcome would depend on the relative input of the population and human capital to the economy.

Furthermore, Eze and Eze (2014) investigated the effects of an increase in population on growth in the economy. The study used GDP growth per capita in lieu of economic growth. ARDL test to Cointegration was used for the analysis. The study revealed a long-run sustainable equilibrium between economic growth and population growth through the use of the ARDL. The study again revealed a unidirectional causality between the population and the economic growth through the use of the pairwise Granger Causality test technique. This implies a positive relationship between economic growth and population growth in the long-run, contrary to Afzal and Awais (2014); and Klasen and Lawson (2007). From the same research perspective, Adenola and Saibu (2017) examined the impact of population growth on economic growth in the long-run on the Nigerian economy. Unlike Eze and Eze (2014), their study adopted the fully modified ordinary least square method and found that the benefits from the working population had not been fully maximized by the Nigerian economy. They, therefore, recommended the need for the government to spur the populace to engage in productive activities which will further trigger economic growth.

Along the same research line, Mahmud (2015) focused on the Indian economy to examine the relationship between population growth and economic growth. Using the Johansen cointegration test and VECM, the study found a positive relationship between population and economic growth and also a uni-directional relationship from economic growth to population growth. This causal relationship is in contradiction to the findings of Eze and Eze (2014) in their study carried out in Nigeria. The study recommended the need to invest in human capital and optimize utilization so as to achieve long-run economic growth. Tartiyus et al. (2015) also examined the impact of population on economic growth in Nigeria between 1980 and 2010. In line with findings from Eze and Eze (2014) and Mahmud (2015), the study found a positive relationship between an average increase in population and economic growth in Nigeria. The study recommended that it is important to maintain an average population growth if sustained economic growth will be experienced.

Examining the long-run benefits of population growth, the study by Simon (2019) found similar results with those of Afzal and Awais (2014) and Klasen and Lawson (2007) in the short run. Simon (2019) observed that an increase in population in the short run places a negative impact on the standard of living as a result of diminishing returns and the transient responsibility it places upon society. It, however, comes with a positive impact on standards of living in the long-run due to knowledge advances and economies of scale. Using a simulation design, it was discovered by the studies that in the long-run, (30-100 years later) when juxtaposed with constant-size population, an average increase in population, enhances living conditions in developed and underdeveloped nations. We, thus, see similar results 
JHASS
3,4

286

with those of Eze and Eze (2014), Mahmud (2015); Tartiyus et al. (2015) in the long-run analysis. Over the long term, a growing population tends to advance knowledge, which, in turn, increases productivity and output at a higher rate than that of population growth. The study, thus, established advantages of increased population growth with respect to the economic growth of underdeveloped nations.

Following an empirical and theoretical path, Bucci et al. (2019) examined the "dilution effect" of population growth on per-capita human capital formation. The dilution effect (discussed in respect of average years of schooling at the individual level and average human capital at the aggregate level) examined the addition of new-borns (who are uneducated) which then reduced both the long-run and short-run level of physical capital per capita. Bucci et al. (2019) showed that the dilution effect was heterogenous and peculiar for each country. The regression analysis revealed that countries with high dilution effects experienced the negative relationship between population growth and economic growth while an "ambiguous" relationship (i.e. negative, neutral or positive) existed between population growth and economic growth in countries with low dilution effect. Along with a similar research thought, Furuoka (2016) examined the advantage of high population growth in the Indian economy. Using ARDL, the study also found a negative long-run relationship between population growth and economic growth and recommended that a continued increase in population may be detrimental to the Indian economy. All these results further complement those of Afzal and Awais (2014) and Klasen and Lawson (2007).

From another research perspective, Bashir et al. (2012) focused on the period between 1972 and 2010 to examine the cointegrating relationship between education, health and employment. VECM and co-integration examination were carried out. Conclusively, the examination revealed long-run expenses on education, health and rate of population, as prominent means of maintaining the rate of employment in Pakistan. In the end, it is suggested that there should be more spending on education to support enrolment at primary and expert levels by offering scholarships to students. For superior health and education, the government ought to expand expenses on health also. In the development of the level of employment, they are crucial players, they also perform important functions in economic and output growth through the availability of similar opportunities in the health and education sector to every individual of any nation all differences can be removed. A review of this research shows the crucial roles of health and education in minimising the rate of unemployment in the long-run and short-run. The minimum wage has also been seen to be a determining factor in employment decisions. While Zavodny (2000) observed that minimum wage had a significant negative effect on employment; Schmitz (2017) observed that minimum wage increases may lower employment but do not affect working hours.

Analysing local employment enlargement for the case of West Germany (1977-2009) Suedekum, Blien and Wolf (2012) kept the impact of human capital and population growth as independent factors and arrived at reasons why countries with the skilled populace, grow rapidly than countries with the less skilled population. A huge portion of a very skilled workforce reduced the consecutive rise in jobs requiring the skilled workforce. Positive impact observed on total employment growth by an increase in human capital and population growth evaluates that jobs demanding low skills are quick to increase than jobs requiring high skills. This study concludes a significant link between human capital, population growth and employment growth.

Another line of study attempted to study the importance of human capital utilization and development for sectoral and national growth. Aliyu et al. (2014) examined the role of human resource development plays in the banking sector in Malaysia and Nigeria. Using regression analysis, the study found that there exists a significant positive relationship between human 
resources development and the performance of banks in the two economies studied. The study, therefore, recommended greater investment in their human resources. In a broader perspective, Jaiyeoba (2015) examined the relationship between investment in human capital and economic growth in Nigeria. Using ordinary least squares, findings show a long-run relationship between human capital development and economic growth in Nigeria. Concluding along the same research line as Aliyu et al. (2014), the study recommended increased investment in education and health, the two major factors that enhance human capital development. This is quite contrary to the propositions of Bucci et al. (2019) and Furuoka (2016).

\section{Methodology}

\subsection{Model specification}

Based on the theoretical underpinning of the work of optimistic theory by Bosernp (1965) which takes into cognizance population growth and human resource utilization; this paper seeks to evaluate the effect of increasing population on human resource utilization in Nigeria. In this study, the employment rate is used as a proxy for human resource utilization. Employment rate was used as the proxy as opposed to measures of human productivity, human resource allocation, availability or levels of human skills due to paucity of data. Following previous studies by Adenola and Saibu (2017), Furuoka (2016), Zavodny (2000) and Schmitz (2017), independent variables to be considered in this study are population growth rate, expected years of schooling and minimum wage. Data was obtained from the World Development Indicator (WDI) and Human Development Report (2019) covering a time span of 1990-2018. The time period is adopted due to available data and because it spans through the oil boom, the economic crisis, as well as the post-structural adjustment periods and the global economic recession - within which population stimulants have undergone different rhythms.

If the variables are of order $\mathrm{I}(0)$ and co-integration has been seen among the variables, then it implies a long-run relationship and there will be a need to apply the vector error correction model (VECM) as specified by Engle and Granger (1987). The VECM does not only involve the explanation of functional relationship but also a good or the best prediction of variation influence of independent factors on the dependent variable.

The functional model to be estimated in this study is, thus, specified below:

$$
E M P=f(P G R, L A F R, E Y S)
$$

where:

$\mathrm{EMP}=$ employment rate;

$\mathrm{PGR}=$ population growth rate;

EYS = expected years of schooling; and

$\mathrm{MW}=$ minimum wage.

The econometric form of the model is given as:

$$
E M P=\beta_{0}+\beta_{1} P G R+\beta_{2} E Y S+\beta_{3} M W+\cup_{t}
$$

where,

$\cup_{t}$ is a random error term representing all other variables not specified in the model

The regression equation of the VECM is as follows: 
JHASS

3,4

288

$$
\begin{aligned}
\Delta Y_{t} & =\alpha_{1}+\sum_{i=1}^{j} \beta_{1} \Delta Y_{t-i}+\sum_{i=1}^{j} \varphi_{1 i} \Delta X_{t-i}+\sum_{i=1}^{j} \varphi_{1 i} \Delta X_{t-i}+\sum_{i=1}^{j} \gamma_{1 i} Z_{t-i} \\
\Delta X_{t} & =\alpha_{2}+\sum_{i=1}^{j} \beta_{2} \Delta Y_{t-i}+\sum_{i=1}^{j} \varphi_{2 i} \Delta Y_{t-i}+\sum_{i=1}^{j} \varphi_{1 i} \Delta X_{t-i}+\sum_{i=1}^{j} Y_{2 i} Z_{t-i}
\end{aligned}
$$

where:

$Y_{t} \quad=$ employment rate;

$X_{t} \quad=$ independent variables;

$\Delta \quad=$ difference operator;

$\alpha_{1}$ and $\alpha_{2}=$ constants;

$\varphi_{1}$ and $\varphi_{2}=$ short run coefficients; and

$Y_{1}$ and $Y_{2}=$ error correction term derived from the long-run cointegrating relationship.

\section{Empirical results and discussions}

\subsection{Trend analysis}

Figure 1 shows the trend of employment rate and population growth rate between 1990 and 2018. Between 1990 and 1992, although there was a drop in population growth rate, the employment rate kept rising. However, beginning in 1992, the employment rate started to drop as the population began to rise. Since the decline in 1992, the employment rate only began to increase in 2004 as the population increased. A further decrease was then experienced in both employment and population growth rate between 2014 and 2016. While there was a continued decline in population growth rate, the employment rate increased between 2016 and 2017 before dropping again in 2018. While the employment growth rate in Nigeria has not been stable over the years, it is saddening to note that it has reduced from $53.8 \%$ in 1990 to $51.9 \%$ in 2018 . The impact of this difference can be seen as drastic with the

\section{Employment Rate Vs Population Growth Rate in \\ Nigeria}

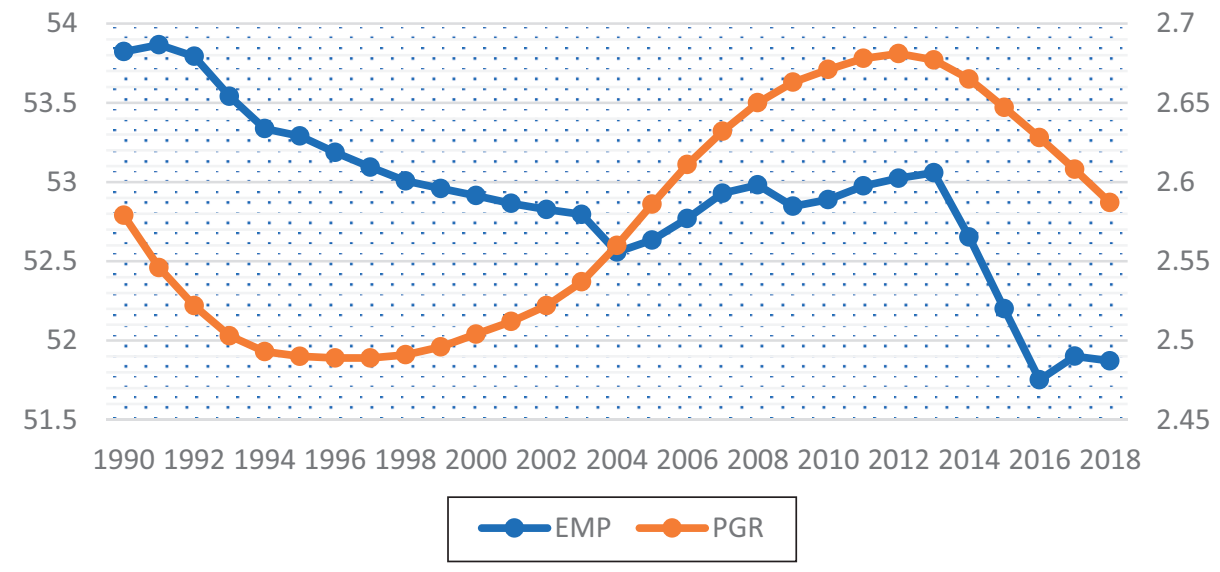

\section{Figure 1.}

Trend analysis of employment rate and population growth in Nigeria 
understanding that the Nigerian population was just 95.27 million in 1990 compared to over 190 million in 2018 (World Bank, 2019).

\subsection{Descriptive statistics results}

Table 1 presents the results of the descriptive statistics of employment rate, population growth rate, estimated years of schooling and minimum wage from 1990 to 2018.

The descriptive statistics show that the highest employment rate within the period under study was $54 \%$ while the lowest stood at $52 \%$. The highest population growth rate was also $2.6 \%$ while the lowest stood at $2.5 \%$. There appears to be a significant difference in the minimum wage as the minimum value is N250 (less than \$1) while the maximum was N30,000 (about \$83) which is currently the minimum wage in the country. Despite this significant increase in the minimum wage, the welfare of the citizens has not been impressive as increased poverty and unemployment are major features of the Nigerian economy (Adelowokan, et al., 2019; Olotu, Salami and Akeremale, 2015). The Jacque bera test shows that the variables are normally distributed with the probabilities not significant at $5 \%$.

\subsection{Unit root test}

Literature has discovered that many time series factors are not fixed which makes the application of changing factors to the model, result in false regression which will not determine accurate prediction (Gujarati, 2003). Hence, our first step is to examine the order of integration of the series, using the Augmented Dickey-Fuller (Dickey and Fuller, 1979) and Phillips- Perron tests (Phillips and Peron, 1988).

Table 2 shows that the variables are of the same order, thus, we conclude that all the variables have a unit root at I(1). That is, a short-run equilibrium exists between the variables. We then apply the use of Johansen and Juselius (1990) co-integration technique model to predict the availability of a long-run relationship among these variables.

\subsection{Co-integrating result}

Table 3 reveals the cointegration test of the variables used in this study. There are two cointegrating equations which show that there are no spurious correlations and prove the existence of long-run relationship among the variables.

\begin{tabular}{lcccc}
\hline & EMP & PGR & EYS & MW \\
\hline Mean & 52.90841 & 2.576448 & 8.106897 & $7,956.897$ \\
Median & 52.929 & 2.579 & 8 & 6,000 \\
Maximum & 53.866 & 2.681 & 9.7 & 30,000 \\
Minimum & 51.752 & 2.489 & 6.7 & 250 \\
Std. dev. & 0.523451 & 0.070998 & 1.000689 & $8,410.524$ \\
Skewness & -0.346032 & 0.137795 & 0.031262 & 0.837697 \\
Kurtosis & 3.264361 & 1.470314 & 1.817862 & 2.634859 \\
Jarque-Bera & 0.66318 & 2.9192 & 1.69331 & 3.55283 \\
Probability & 0.717782 & 0.232329 & 0.428847 & 0.169244 \\
Sum & $1,534.344$ & 74.717 & 235.1 & 230750 \\
Sum Sq. dev. & 7.672027 & 0.141141 & 28.03862 & $1.98 \mathrm{E}+09$ \\
Observations & 29 & 29 & 29 & 29
\end{tabular}

Source: Authors' computation, 2020

Table 1. Summary statistics 


\section{JHASS 3,4}

290

\subsection{Vector error correction model}

As the factors are co-integrated for a long-run relationship, an Error Correction Model was computed to ascertain the speed at which shocks can be corrected in the long-run; the outcome derived is presented in Table 4.

Table 4 presents the long-run and short-run effect of population growth rate, expected years of schooling and minimum wage on the employment rate. In the short run, there is a positive relationship between population growth rate and employment growth rate; however, in the long-run, the population growth rate shows a negative relationship with the employment growth rate. Expected years of schooling and minimum wage also reveal a positive relationship. In the long-run, a percent increase in population growth rate will reduce the employment growth rate by $-7.99 \%$ which shows a very huge effect; this relationship is, however, positive in the short run. A percent increase in expected years of schooling will, however, increase the employment growth rate by $0.65 \%$. This shows the relevance of education in human resource utilization while increased growth rate may be inimical to the utilization of human resources in the economy. This effect of an increase in the minimum wage is also quite significant in the employment growth rate. Contrary to findings by Zavodny (2000) and Schmitz (2017) where minimum wage negatively impacted employment decisions, this research shows that a percent increase in the minimum wage is capable of increasing the employment growth rate by $3.6 \%$. Our findings, thus, show that an increase in population growth rate may be disadvantageous to human resource utilization (this is also in line with outcomes from Furuoka, 2016 and Simon, 2019) while years of schooling and minimum wage play more important roles in influencing human resource utilization.

\begin{tabular}{lcccccc}
\hline Variables & ADF statistics & Critical values & $\begin{array}{c}\text { Order of } \\
\text { integration }\end{array}$ & PP statistics & $\begin{array}{c}\text { Critical } \\
\text { values }\end{array}$ & $\begin{array}{c}\text { Order of } \\
\text { integration }\end{array}$ \\
\hline EMP & -3.3155 & -2.9763 & $\mathrm{I}(1)$ & $*-1.8815$ & -1.9534 & $\mathrm{I}(1)$ \\
PGR & $*-1.7341$ & -1.955 & $1(1)$ & -2.0567 & -1.9539 & $1(1)$ \\
EYS & -5.9473 & -2.9763 & $\mathrm{I}(1)$ & -5.9474 & -2.9763 & $\mathrm{I}(1)$ \\
MW & -4.2521 & -2.9763 & $\mathrm{I}(1)$ & -4.2521 & -2.9763 & $\mathrm{I}(1)$
\end{tabular}

Table 2.

Source: Authors' computation. Indicates statistical significance level at 10\%

\begin{tabular}{|c|c|c|c|c|}
\hline \multicolumn{5}{|c|}{ Unrestricted co-integration rank test (trace) } \\
\hline Hypothesized & & Trace & 0.05 & \\
\hline No. of CE(s) & Eigenvalue & Statistic & Critical value & Prob.** \\
\hline None* & 0.675031 & 65.38279 & 47.85613 & 0.0005 \\
\hline At most $1 *$ & 0.600859 & 35.03409 & 29.79707 & 0.0114 \\
\hline At most 2 & 0.315519 & 10.23622 & 15.49471 & 0.263 \\
\hline At most 3 & 2.47E-05 & 0.000667 & 3.841466 & 0.9807 \\
\hline \multicolumn{5}{|c|}{$\begin{array}{l}\text { Notes: Trace test indicates two cointegrating eqn(s) at the } 0.05 \text { level. }{ }^{*} \text { Denotes rejection of the hypothesis at } \\
\text { the } 0.05 \text { level. }{ }^{* *} \text { MacKinnon-Haug-Michelis }(1999) \text { p-values } \\
\text { Source: Authors' computation }\end{array}$} \\
\hline
\end{tabular}

Table 3.

Johansen cointegration test 
लํㅏ응

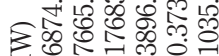

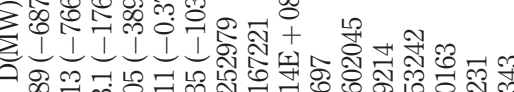

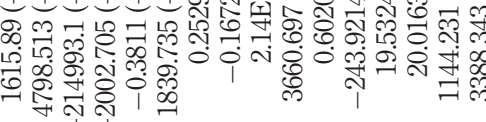

Population

growth

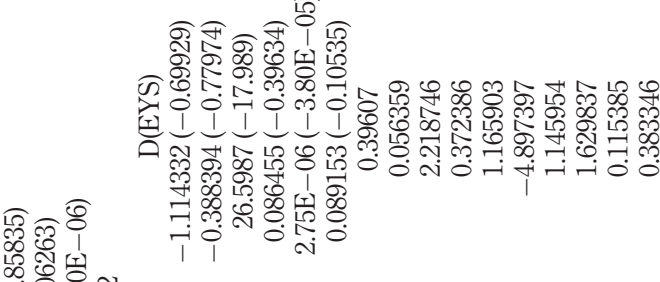

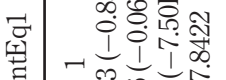

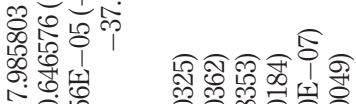

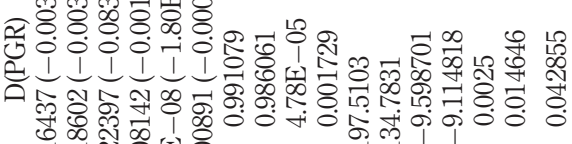

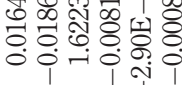

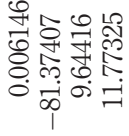

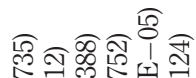

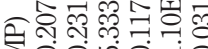

年

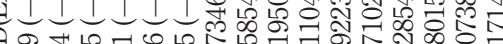

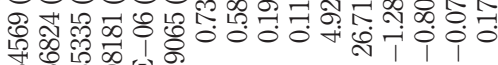

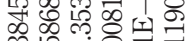

品

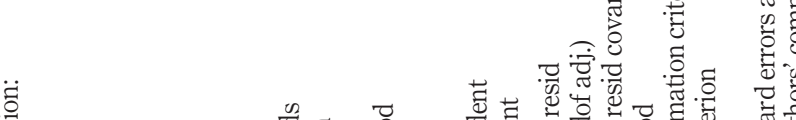


JHASS
3,4

The coefficient of determination of 0.73 indicates that $73 \%$ of the total variation in employment rate is explained by the population growth rate, expected years of schooling and minimum wage during the period of this study while other exogenous variables account for about $27 \%$ of the variation in the employment rate. This implies that population growth rate, expected years of schooling and minimum wage had a significant implication on employment rate position in Nigeria during the period of this study. Finally, the ECM measures the speed of adjustment of variations due to unexpected shocks. The ECM is negative (-0.384569) and significant which indicates a long-run causality from population growth rate, expected years of schooling and minimum wage to the employment growth rate. It also shows that disequilibrium in the previous periods is adjusted at a speed of about $38 \%$ annually.

\subsection{Granger causality test}

Having established that there is a long-run correlation among the variables, the objective of this section is to determine the direction of the causality among the variables during the period 1990 to 2018.

Table 5 reveals that unidirectional causality runs from employment rate to population growth rate and also a unidirectional causality also runs from employment growth rate to expected years of schooling. Also, there is a unidirectional causality relationship from minimum wage to employment growth rate at $10 \%$ level of significance. This shows that while the employment rate can cause the population to increase, population growth does not cause employment growth. On the other hand, the minimum wage can cause the employment growth rate to increase but the employment growth rate cannot cause minimum wage.

\subsection{Impulse response function}

Figure 2 reveals the impulse response function showing the responsiveness of employment growth rate to shocks in employment growth rate, population growth rate, expected years of schooling and minimum wage up to period 10 . The impulse response function is depicted by the thick lines.

\begin{tabular}{lccr}
\hline Null hypothesis: & Obs & $F$-statistic & Prob. \\
\hline PGR does not Granger Cause EMP & 27 & 1.61753 & 0.2211 \\
EMP does not Granger Cause PGR & & 0.19023 & 0.8281 \\
EYS does not Granger Cause EMP & 27 & 1.36915 & 0.2752 \\
EMP does not Granger Cause EYS & & 3.75907 & 0.0394 \\
MW does not Granger Cause EMP & 27 & $2.71593 *$ & 0.0883 \\
EMP does not Granger Cause MW & 27 & 2.06588 & 0.1506 \\
EYS does not Granger Cause PGR & & 0.44844 & 0.6443 \\
PGR does not Granger Cause EYS & 27 & 0.01255 & 0.9875 \\
MW does not Granger Cause PGR & & 0.75543 & 0.4816 \\
PGR does not Granger Cause MW & 27 & 0.23223 & 0.7947 \\
MW does not Granger Cause EYS & & 1.14787 & 0.3356 \\
EYS does not Granger Cause MW & & 2.08772 & 0.1478
\end{tabular}

Table 5.

Granger causality test result
Note: *Denotes significance at $10 \%$ Source: Authors' computation, 2020 

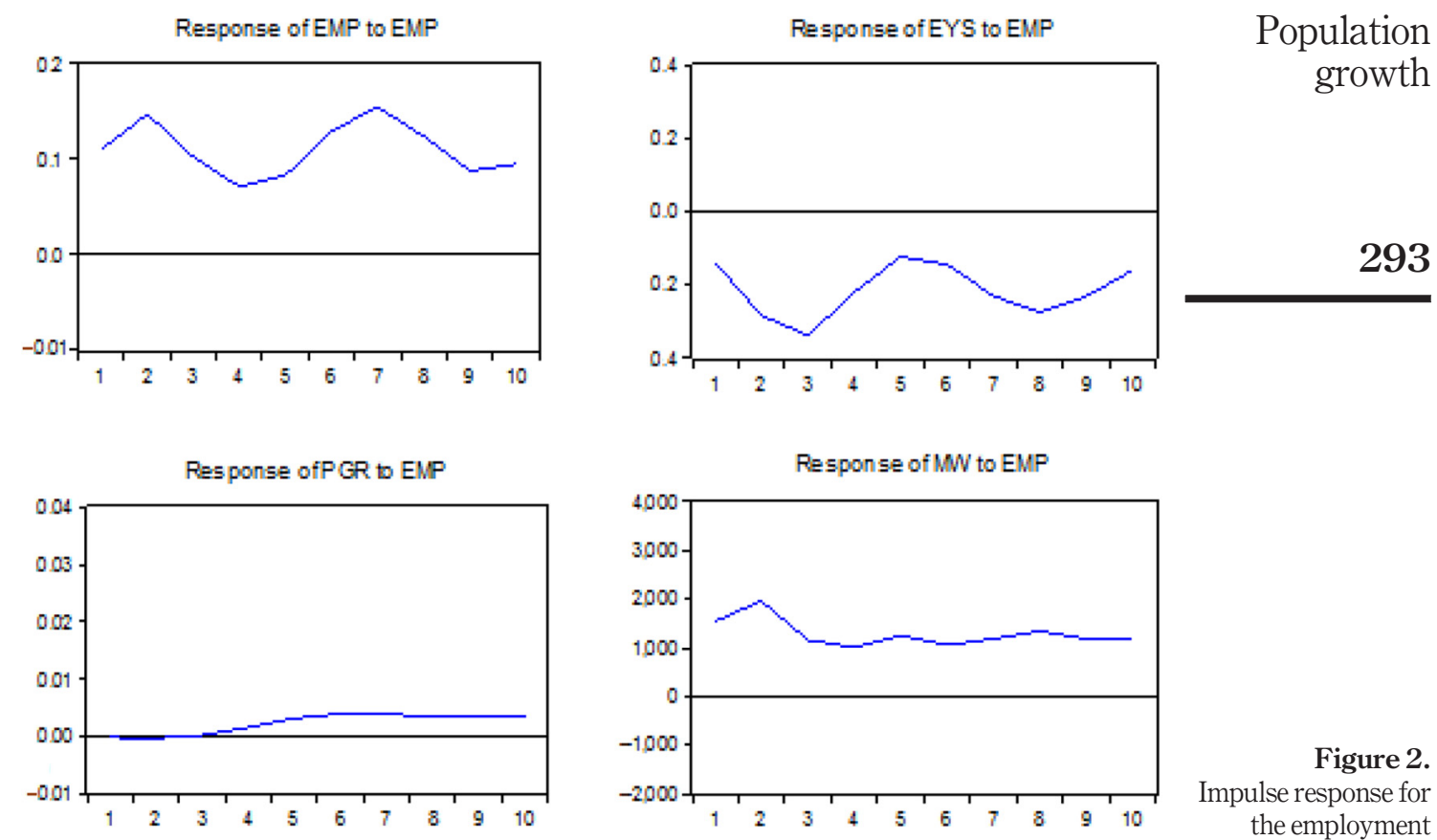

Source: Authors computation 2020

Figure 2.

Impulse response for the employment growth rate equations

The response of employment rate to itself shows that shocks in employment rate indicate a positive impact all from the first period to the tenth period, albeit at different degrees. The response of expected years of schooling to employment growth rate, however, showed varying negative impact all through the 10 periods. For the response of population growth rate to employment growth rate, there seems to be a zero-impact from period one to four, after which a positive impact is seen over periods five to ten. The correlations among employment growth rates and identified independent variables can, thus, be seen to be relatively complex.

\section{Conclusion and recommendations}

The main drifts of this research are to examine the impact of population growth on human resource utilization in Nigeria and also to investigate the direction of causality between them. In a bid to accomplish these objectives, the population growth rate measured in the annual growth rate was instead used for population growth while the employment rate was used as a proxy for human resource utilization. Using a time-series data from 1990 to 2018 sourced from the World Development Index (WDI) and United Nations Report, the Augmented Dickey-Fuller, Philip Perron test and Johansen's co-integration technique were used to examine the unit root and also for the confirmation of co-integration among the respective factors. The results from the unit root and Johansen co-integrating equation revealed that long-run relationships exist between employment rate, population growth rate, expected years of schooling and minimum wage.

In a bid to investigate their long-run relationship, this study has used the use of VECM to ascertain the speed at which shocks can be corrected in the long-run. The result from the 
JHASS
3,4

VECM revealed that the population growth rate has a negative relationship and a significant effect on the employment rate in Nigeria. This implies that an increase in population growth rate in Nigeria does not increase the number of populace used in the labour market. This is because the effect of the supply of labour on unemployment would be the opposite of the request for labour effects. Our findings show that the Optimistic theory does not apply to the Nigerian economy. A number of factors determine the supply of labour in an economy and the chief among them is the level of growth in population. Furthermore, the result from the Granger causality test shows a single-direction course flowing from employment rate to expected years of schooling and from minimum wage to employment in Nigeria. This implies that the employment growth rate has a predictive effect on expected years of schooling in Nigeria and the minimum wage also has the ability to predict the employment rate in Nigeria. There has been a moderate increase in the minimum wage in Nigeria over the years, therefore, employers may not find it difficult to pay the minimum wage to their workers bearing in mind inflation and other macroeconomic factors in the economy. This study has to some extent enhanced our understanding of the relationship between population growth and human capital utilization with the general findings of the study pointing to the fact that population growth in Nigeria may not lead to a rise in the utilization of human resources.

Based on our analysis and research findings, this study, therefore, recommends that Nigeria needs to adopt a skilled-oriented education principle to train skilled and technically strong manpower, so as to build and maintain its critical infrastructure to drive the economy. Following the significant relationship in expected years of schooling and employment rate in Nigeria, an increase in skill-oriented education during the period of formal education in the country will boost employment as graduates need not find white-collar jobs to be used or engaged in productive activities. This will, thus, lead to good utilization of human capital. Furthermore, the notion that population increase in Nigeria is a key to the control of political power and resources should be discarded and proactive approach such as engaging in labour-intensive projects, industrial development projects capable of absorbing a large number of labour, large scale farming to make available food and security for the incessantly rising population should be adopted.

A major limitation of this study is the use of the employment rate as a proxy for human capital utilization. This may be less than desirable; howbeit we are constrained in the absence of any other viable options. Future studies can adopt measures that greater capture human productivity, human resource allocation and levels of human skills; to examine the interactive effect on economic productivity.

\section{References}

Adelowokan, O.A., Maku, O.E., Babasanya, A.O. and Adesoye, A.B. (2019), "Unemployment, poverty and economic growth in Nigeria", Journal of Economics and Management, Vol. 35, pp. 5-17.

Adenola, F. and Saibu, O.M. (2017), "Does population change matter for long run economic growth in Nigeria?", International Journal of Development and Sustainability, Vol. 6 No. 12, pp. 1955-1965.

Adeomola, A. and Badiru, A. (2016), "The impact of unemployment and inflation on economic growth in Nigeria (1981-2014)", International Journal of Business and Economic Sciences Applied Research (IJBESAR), Vol. 9 No. 1, pp. 47-55.

Adepoju, A. (2007), "Highly skilled migration: balancing interests and responsibilities and tackling brain drain", Being a paper presented at the Global Forum on Migration and Development, Civil Society Day, 9-11 July 2007, Brussels. 
Adewole, A.O. (2012), "Effect of population on economic development in Nigeria: a quantitative assessment", International Journal of Physical and Social Sciences, Vol. 4 No. 2, pp. 47-51, Online ISSN: 2249-5894.

Adeyemi, T.O. (2009), "The effective management of primary schools in Ekiti state, Nigeria: an analytical assessment”, Educational Research and Reviews, Vol. 4 No. 2, pp. 48-56.

Afolayan, O.T., Okodua, H., Matthew, O. and Osabohien, R. (2019), "Reducing unemployment malaise in Nigeria: the role of electricity consumption and human capital development", International Journal of Energy Economics and Policy, Vol. 9 No. 4, pp. 63-73.

Afzal, M. and Awais, S. (2014), "Population and poverty nexus in Pakistan", Journal of Independent Studies and Research, Vol. 12 No. 2, pp. 63-75.

Ahmed, E.M. (2017), "ICT and human capital spillover effects in achieving sustainable East Asian knowledge-based economies", Journal of the Knowledge Economy, Vol. 8 No. 3, pp. 1086-1111.

Ajide, K.B. and Ridwan, I.L. (2018), "Deterrents to human capital development in Nigeria", Unilag Journal of Humanities, Vol. 6 No. 2, pp. 69-89.

Ali, M., Egbetokun, A. and Memon, M. (2018), "Human capital, social capabilities and economic growth”, Economies, Vol. 6 No. 1, pp. 1-18, doi: 10.3390/economies6010002.

Aliyu, M.G., Kusairi, S. and Muhamad, S. (2014), "Investing in human resource development: empirical evidence from banking institutions of Malaysia and Nigeria", Journal of Economics and Sustainable Development, Vol. 5 No. 12, pp. 123-132.

Aloysius, O.I., Ismail, I.A., Suandi, T. and Arshad, M.M. (2018), "Enhancing university's and industry's employability-collaboration among Nigeria graduates in the labor market", International Journal of Academic Research in Business and Social Sciences, Vol. 8 No. 7, pp. 32-48.

Anson, J., Bartl, W. and Kulczycki, A. (2019), "Roots and fruits of population growth and social structures: demographic and sociological vistas", In Studies in the Sociology of Population, Springer, Cham, pp. 1-24.

Bashir, F., Farooq, S., Nawaz, S., Bagum, M., Sandila, M.A. and Arshad, M.R. (2012), "Education, health and employment in Pakistan: a co-integration analysis", International Journal of Humanities and Social Science, Vol. 2 No. 5, pp. 53-64.

Bell, M., Charles-Edwards, E., Ueffing, P., Stillwell, J., Kupiszewski, M. and Kupiszewska, D. (2015), "Internal migration and development: comparing migration intensities around the world", Population and Development Review, Vol. 41 No. 1, pp. 33-35.

Bosernp, E. (1965), The Conditions of Agricultural Growth: The Economics of Agrarian Change under Population Pressure, Aldine, Chicago, IL.

Bucci, A., Eraydın, L. and Müller, M. (2019), "Dilution effects, population growth and economic growth under human capital accumulation and endogenous technological change", Journal of Macroeconomics, Vol. 62, doi: 10.1016/j.jmacro.2018.08.003.

Chae, H.C., Koh, C.E. and Park, K.O. (2018), "Information technology capability and firm performance: role of industry", Information and Management, Vol. 55 No. 5, pp. 525-546.

Cunningham, L.X. (2010), "Managing human resources in SMEs in a transition economy: evidence from China", The International Journal of Human Resource Management, Vol. 21 No. 12, pp. 2120-2141, doi: 10.1080/09585192.2010.509620.

Dao, M.Q. (2012), "Population and economic growth in developing countries", International Journal of Academic Research in Business and Social Sciences, Vol. 2 No. 1, pp. 6-17.

Deliu, A.M. and Ilea, L.T. (2018), "Combined and uneven feminism: intersectional and post constructivist tendencies", Metacritic Journal for Comparative Studies and Theory, Vol. 4 No. 1, p. 5 .

Dickey, D.A. and Fuller, W.A. (1979), "Distribution of the estimators for autoregressive time series with a unit root", Journal of the American Statistical Association, Vol. 74 No. 366, pp. 427-431. 


\section{JHASS 3,4}

Emeh, I.E.J. (2012), "Tackling youth unemployment in Nigeria; the Lagos state development and empowerment programmes initiatives", Afro Asian Journal of Social Sciences, Vol. 3 No. 4, pp. 1-30.

Engle, R.F. and Granger, C.W. (1987), "Co-integration and error correction: representation, estimation, and testing", Econometrica, Vol. 55 No. 2, pp. 251-276.

Erdogan, M. and Unver, M. (2015), "Determinants of foreign direct investments: dynamic panel data evidence", International Journal of Economics and Finance, Vol. 7 No. 5, p. 82.

Essien, E.B. (2016), "Population growth and economic growth performance in Nigeria (1981-2014)", Turkish Economic Review, Vol. 3 No. 1, pp. 143-159.

Eze, B.I. and Eze, N.J. (2014), "Demographic, socio-economic and clinical characteristics: implications for time to presentation at a Nigerian tertiary ophthalmic outpatient population", Public Health, Vol. 128 No. 11, pp. 1023-1029, doi: 10.1016/j.puhe.2014.09.003.

Fapohunda, T.M. (2012), "The global economic recession: impact and strategies for human resources management in Nigeria", International Journal of Economics and Management Sciences, Vol. 1 No. 6, pp. 7-12.

Furuoka, F. (2016), "Is population beneficial to economic growth? An empirical study of China", Quality and Quantity, Vol. 52 No. 1, pp. 209-225, doi: 10.1007/s11135-016-0463-6.

Gatawa, N., Elijah, S. and Mohammed, U.M. (2018), "An empirical analysis of the impact of floating exchange rate on balance of payment in Nigeria (1986-2016)", Turkish Economic Review, Vol. 5 No. 3, pp. 285-307.

Gujarati, N.D. (2003), Basic Econometrics, 4th ed., Tata McGraw-Hill, New Delhi, pp. 748- 807.

Hendrixson, A., Ojeda, D., Sasser, J.S., Nadimpally, S., Foley, E.E. and Bhatia, R. (2020), "Confronting populationism: feminist challenges to population control in an era of climate change", Gender, Place and Culture, Vol. 27 No. 3, pp. 307-315.

Human Development Report (2019), "Inequalities in human development in the 21st century briefing note for countries on the 2019 human development report by the united nations development programme", available at: http://hdr.undp.org/sites/all/themes/hdr_theme/country-notes/NGA. pdf (accessed 27 March 2020).

Isiaka, M.A. and Oghenekevwe, I.J. (2019), "Towards resolving the tension between democracy and bureaucracy in the human resources procurement in the Nigerian fourth republic public service", Dynamics of Public Administration, Vol. 36 No. 1, pp. 85-95.

Jaiyeoba, S.V. (2015), "Human capital investment and economic growth in Nigeria", African Research Review, Vol. 9 No. 1, pp. 30-46.

Jha, N.K. and Saritha, R. (2019), "Female labour force participation (FLFP) and its significance in economic growth of India: an overview", Research Journal of Humanities and Social Sciences, Vol. 10 No. 2, pp. 270-278.

Johansen, S. and Juselius, K. (1990), "Maximum likelihood estimation and inference on cointegration with applications to demand for money", Oxford Bulletin of Economics and Statistics, Vol. 52 No. 2, pp. 169-210.

Klasen, S. and Lawson, D. (2007), "The impact of population growth on economic growth and poverty reduction in Uganda", Discussion contributions from the Economics Department of the University of Göttingen No. 133.

Kuznets, S., Quandt, R. and Friedman, M. (1960), "Population change and aggregate output", in Universities-National Bureau. Demographic and Economic Change in Developed Countries, UMI, pp. 340-367.

Longe, O. (2017), "Graduate unemployment in Nigeria: causes, consequences and remediable approaches", American International Journal of Contemporary Research, Vol 7 No. 4, pp. 63-73.

MacKinnon, J., Haug, A. and Michelis, L. (1999), "Numerical distribution functions of likelihood ratio tests for cointegration", Journal of Applied Econometrics, Vol. 14 No. 5, pp. 563-577. 
Mahmud, A.M. (2015), "Econometric model on population growth and economic development in India: an empirical analysis", Proceedings of the International Symposium on Emerging Trends in Social Science Research, Vol. 6 No. 3, pp. 1-82.

National Bureau of Statistics (2009), available at: www.nigeriansta.gov.ng

Nauman, E., VanLandingham, M. and Anglewicz, P. (2016), "Migration, urbanization and health", In International Handbook of Migration and Population Distribution, Springer, Dordrecht, pp. 451-463.

Nyoni, T. and Bonga, W.G. (2018), "What determines economic growth in Nigeria?", Dynamic Research Journals (DRJ) Journal of Business and Management, Vol. 1 No. 1, pp. 37-47.

Ogunleye-Adetona, C.I. (2010), "Human resources and economic development in Nigeria", Journal of Sustainable Development in Africa, Vol. 12 No. 3, pp. 204-211.

Okoye, P.V.C. and Ezejiofor, R.A. (2013), "The effect of human resources development on organizational productivity", International Journal of Academic Research in Business and Social Sciences, Vol. 3 No. 10, pp. 250-268.

Olotu, A., Salami, R. and Akeremale, I. (2015), "Poverty and rate of unemployment in Nigeria", International Journal of Management, Vol. 2 No. 1, pp. 1-4.

Onwuka, E.C. (2006), “Another look at the impact of Nigeria's growing population on the country's development", African Population Studies, Vol. 21 No. 1.

Pandya, V. and Sisombat, S. (2017), "Impacts of foreign direct investment on economic growth: empirical evidence from Australian economy", International Journal of Economics and Finance, Vol. 9 No. 5, pp. 121-131.

Phillips, P.C. and Peron, P. (1988), “Testing for a unit root in time series regression”, Biometrika, Vol. 75 No. 2, pp. 335-346.

Saghir, J. and Santoro, J. (2018), "Urbanization in Sub-Saharan Africa”, Center For Strategic And International Studies Report, Washington, DC, available at: www.csis.org

Sankay, O.J., Ismail, R. and Shaari, A.H. (2010), "The impact of human capital development on the economic growth of Nigeria", Prosiding Perkem, Vol. 5 No. 1, pp. 63-72.

Schmitz, S. (2017), "The effects of Germany's new minimum wage on employment and welfare dependency", Diskussionsbeiträge, 21, Freie Universität Berlin, Fachbereich Wirtschaftswissenschaft, Berlin.

Simon, J.L. (2019), The Economics of Population Growth, Labour Economics, Princeton Legacy Library, Princeton University Press.

Suedekum, J., Blien, U. and Wolf, K. (2012), "Local employment growth in West Germany: a dynamic panel approach", Labour Economics, Vol. 13 No. 4, pp. 445-458.

Swain, R.B. (2018), "A critical analysis of the sustainable development goals", In Handbook of Sustainability Science and Research, Springer, Cham, pp. 341-355.

Tartiyus, E.H., Dauda, M.I. and Peter, A. (2015), "Impact of population growth on economic growth in Nigeria (1980-2010)", IOSR Journal of Humanities and Social Science, Vol. 4 No. 5, pp. 115-123.

Turner, P. (2018), "Retaining talent in health sector organisations", in Talent Management in Healthcare, Palgrave Macmillan, Cham, pp. 285-313.

Uneke, C.J., Sombie, I., Keita, N., Lokossou, V., Johnson, E. and Ongolo-Zogo, P. (2017), "Improving maternal and child health policymaking processes in Nigeria: an assessment of policymakers' needs, barriers and facilitators of evidence-informed policymaking", Health Research Policy and Systems, Vol. 15 No. 1, doi: 10.1186/s12961-017-0217-5.

United Nations (2015), "Transforming our world: the 2030 agenda for sustainable development, New York", United Nations, New York, NY, available at: https://sustainabledevelopment.un.org/ content/documents/21252030 $\% 20$ Agenda $\% 20$ for $\% 20$ Sustainable $\% 20$ Development $\% 20$ web.pdf (accessed 7 March 2016). 
JHASS

3,4

298
World Bank (2016), “Nigeria’s booming population requires more and better jobs”, World Bank, available at: www.worldbank.org/en/news/press-release/2016/03/15/nigerias-booming-population-requiresmore-and-better-jobs (accessed 17 December 2016).

World Bank (2019), World Development Indicators, World Bank Group.

Yakubu, M.M., Akanegbu, B.N. and Jelilov, G. (2020), "Labour force participation and economic growth in Nigeria", Advances in Management and Applied Economics, Vol. 10 No. 1, pp. 1-14.

Zahonogo, P. (2016), "Trade and economic growth in developing countries: evidence from sub-Saharan Africa”, Journal of African Trade, Vol. 3 Nos 1/2, pp. 41-56.

Zavodny, M. (2000), "The effect of the minimum wage on employment and hours", Labour Economics, Vol. 7 No. 6, pp. 729-750, doi: 10.1016/s0927-5371(00)00021-x.

\section{Further reading}

Fox, S., Bloch, R. and Monroy, J. (2018), "Understanding the dynamics of nigeria's urban transition: a refutation of the 'stalled urbanisation' hypothesis", Urban Studies, Vol. 55 No. 5, pp. 947-964.

Hossain, M.Z., Khan, M.O.A. and Ahmed, J.U. (2016), "Determinants of rural-urban migration in Bangladesh including its consequences for origin households and urban amenities", Research and Reviews: Journal of Statistics, Vol. 5 No. 2, pp. 47-61.

National Population Commission (NPC) [Nigeria] (1998), "1991 Population census of the federal republic of Nigeria: analytical report at the national level", Lagos.

\section{Corresponding author}

Oluyemi Theophilus Adeosun can be contacted at: oluyemiadeosun@gmail.com

For instructions on how to order reprints of this article, please visit our website: 